\title{
Transportation Cost of Agricultural Exports from Gaza Strip: An Exploratory Study
}

\author{
Khalil A. Elnamrouty \\ Department of Economics and Political Science, Islamic University - Gaza, Gaza Strip, Palestine \\ Email address: \\ knamroty@iugaza.edu.ps
}

To cite this article:

Khalil A. Elnamrouty. Transportation Cost of Agricultural Exports from Gaza Strip: An Exploratory Study. International Journal of Economics, Finance and Management Sciences Vol. 5, No. 6, 2017, pp. 276-283. doi: 10.11648/j.ijefm.20170506.11

Received: August 3, 2016; Accepted: October 8, 2017; Published: November 10, 2017

\begin{abstract}
Export transportation costs are one of the major obstructions facing the Palestinian economy. The process of moving agricultural goods from the exporter's location in the Gaza Strip to the target market involves significant financial costs as well as costs associated with imperfect information, weak infrastructure, lengthy and uncertain delivery times. The experience of exporters in Gaza Strip proves that, Back-to-Back system at Kerem Shalom crossing point and other procedures imposed by the Israeli occupation has led to an increase in land transport, freight and logistic costs. Consequently, this has caused great losses to the agriculture sector and other economic sectors in the Gaza Strip.
\end{abstract}

Keywords: Transport Cost, Agriculture Export, Israel Occupation, Gaza Strip

\section{Introduction}

In the light of National Export Strategy (2014-2018) and the formation of the Palestinian Council for Exports to support and promote the export sector in order to stimulate demand and to boost growth in the Palestinian economy, the present study aims to focus on the effects of transportation costs on the agricultural exports from the Gaza Strip to some regional, international and Gulf markets.

Export transportation costs are one of the major obstructions facing the Palestinian economy. They reduce the degree of competitiveness because of the Israeli occupation actions against the Palestinian economy, especially in the Gaza Strip. Israel is completely controlling the crossing points and forcing the Palestinian exporters to follow Israeli conditions and specifications. This has led to higher costs and to the damage of some exports because of security procedures and the multiplicity of loading and unloading procedures. Back-to-Back system at the (Kerem Shalom crossing is the only passage for the transport of goods to and from Gaza Strip), Kerem Shalom crossing point is not equipped with suitable infrastructure, in addition to the long time it needs for clearance procedures.

There are several determining key factors affecting the means and costs of transporting goods, (distance, commodity weight, shape, structure and size). Therefore, there is a direct relationship between the costs of transportation and the value of the commodity.

The percentage of transport cost to exported good prices varies from one country to another. Studies ${ }^{1}$ indicate that this ratio is no less than $8 \%$ of the goods value and sometimes goes up to more than $20 \%$ in some countries. According to a study submitted to the Organization for Economic Cooperation and Development (OECD) about the impact of maritime costs on agricultural exports, the study find that more than $90 \%$ of goods exchange between countries is done by maritime, unlike Palestine, most of the agricultural exports are made by land and then by air transport. That said, the cost of land transport is higher than the cost of shipping. The study shows that land transport cost of grain imports in some countries is rated between $20 \%-30 \%$ from the total value, whereas maritime costs reach $10.5 \%$ from the total value in 2007. Generally, the percentage varies according to maritime links between countries, e.g. agriculture import cost for OECD is around $9 \%$, while in developing countries it is

1 Korinek, J. and P. Sourdin (2009), "Clarifying Trade Costs: Maritime Transport and its Effect on Agricultural Trade", OECD Trade Policy Papers, No. 92, OECD Publishing. http://dx.doi.org/10.1787/220157847513 
around $13 \%$ of the goods value.

\section{Literature Review}

In the recent economic literature, there have been several attempts to measure transport costs directly or indirectly. WTO (2004) shows that efficient logistics is an important determinant of a country's competitiveness. The international transport system may suffer from insufficient cross-country coordination of the network, such as non-integrated time schedules, customs delays, incompatible standards or an insufficient flow of information about delays. Efficient logistics does not just reduce costs of transport and transit time, but also decreases the costs of production. Zarzoso, García and Burguet (2008) show that distance variable behaves differently according to the mode of transport. The infrastructure variable is only significant for low value-added sectors, and poor infrastructure leads to a notable increase in transport costs. Christ and Ferrantino (2009) concluded that the costs associated with movement to port in landlocked countries in SSA, (Sub-Saharan Africa) are non-trivial. These costs have three dimensions: financial costs of land transport, opportunity costs of time in slow processes, and uncertainty associated with unpredictable arrival times and incomplete information. These costs are high in accordance with global standards Stone and Strutt (2009) the study shows the clear gains from improvements in physical land transport and the more substantial gains from improved trade facilitation. The implications of these results are that physical infrastructure must be in place for trade to take place. However, once in place, attention should turn to soft aspects of trade facilitation. Behar and Venables (2010) proved that transport costs affect international trade and vice versa. Both are influenced by considerations of geography, technology, infrastructure, fuel costs and policy towards trade facilitation. Distance is not the only important geographical factor. Being landlocked increases trade costs by $50 \%$ and reduces trade volumes by $30-60 \%$, numbers that are broadly consistent with the elasticity of trade with respect to costs given above. Geography is not the only determinant because the hard and soft infrastructure of transport can also offset the geographical disadvantage faced by some countries. Over time, technical changes and the prices of fuel have influenced transport costs and trade volumes. Korinek and Sourdin (2011) noted that the paper finds strong support for a number of hypotheses with important policy implications. First, higher quality trade logistics are positively, significantly and robustly associated with higher bilateral merchandise trade. Second, the impact of improved trade logistics is greater for goods that are transported by air than those via sea. This is possibly due to the fact that time sensitive merchandise requires higher quality logistics services. Third, improvements in port, and particularly air, infrastructure benefit middle-income countries more than lower income countries. Jörn and Julia (2011) pointed out that the study shows that technology choice affects transport prices via the marginal costs of supplying transport services between two locations. If this description of investment in the transport sector is correct, it is not sufficient to approximate transport costs by distance and distance-related variables as done in the vast majority of empirical trade applications. Shepherd (2013) finds that the improvements in value chain performance make it easier to move important goods, such as basic foodstuffs or vaccines to areas outside main population centers, thereby spreading the benefits of development, helping improve access and keeping consumer prices down. Physical infrastructure such as roads, rail links, ports, and air ports remains in serious need of upgrading and maintenance in many developing countries. The rate of improvement in these areas appears to be noticeably slower than ICT infrastructure. UNCTAD (2013) concluded that altering costs, prices, logistics structures and supply chains as well as comparative advantages and related impacts can greatly determine countries' trade performances and competitiveness, especially in developing regions. JeanFrançois Arvis, Duval, Shepherd, and Utoktham (2013) noted that maritime transport connectivity and logistics performance are very important determinants of bilateral trade costs: in some specifications, their combined effect is comparable to that of geographical distance. Coşar and Demir (2015) finds that the cost of an average shipment over a high capacity expressway is about $70 \%$ lower than it is over single-lane roads, and efficient logistics enable countries to take part in global supply chains and exploit their comparative advantages.

\section{Trade Volumes}

The Gaza Strip is a completely blockade area with limited resources, high rate of Poverty and unemployment. Gaza Strip is a small self-governing Palestinian territory on the eastern coast of the Mediterranean Sea, which borders Egypt on the southwest for 11 kilometers $(6.8 \mathrm{mi})$ and Israel on the east and north along a $51 \mathrm{~km}(32 \mathrm{mi})$ border. The territories of Gaza and the West Bank are separated from each other by the territory of Israel. Both fall under the jurisdiction of the Palestinian Authority (Wikipedia). Table (1) shows clearly the weak and highly fluctuated performance of Gaza Strip exports, imports and trade balance related to Palestine GDP.

Table 1. Gaza Strip Trade Balance Relative to Palestine GDP 1994 - 2015 Million US\$.

\begin{tabular}{|c|c|c|c|c|c|c|}
\hline Year & Exports & EXP/GDP* & Imports & IMP/GDP* & Trade Balance & BT/GDP* \\
\hline 1994 & 39.8 & $9.7 \%$ & 700.3 & $33.2 \%$ & -660.5 & $38.8 \%$ \\
\hline 1995 & 43.8 & $8.4 \%$ & 693.3 & $30.1 \%$ & -649.5 & $36.4 \%$ \\
\hline 1996 & 47.0 & $9.4 \%$ & 742.7 & $32.8 \%$ & -695.7 & $39.5 \%$ \\
\hline 1997 & 62.5 & $10.3 \%$ & 787.2 & $31.1 \%$ & -724.7 & $37.6 \%$ \\
\hline
\end{tabular}




\begin{tabular}{lllllll}
\hline Year & Exports & EXP/GDP* & Imports & IMP/GDP* & Trade Balance & BT/GDP* \\
\hline 1998 & 68.7 & $9.7 \%$ & 817.4 & $29.6 \%$ & -748.7 & $36.5 \%$ \\
1999 & 80.9 & $10.8 \%$ & 912.5 & $27.2 \%$ & -831.6 & $32.0 \%$ \\
2000 & 133.1 & $15.1 \%$ & 897.9 & $29.7 \%$ & -764.8 & $35.6 \%$ \\
2001 & 80.9 & $13.7 \%$ & 682.8 & $25.5 \%$ & -601.9 & $28.8 \%$ \\
2002 & 75.2 & $15.6 \%$ & 710.1 & $30.5 \%$ & -634.9 & $34.4 \%$ \\
2003 & 94.9 & $17.6 \%$ & 857.0 & $32.1 \%$ & -762.1 & $35.8 \%$ \\
2004 & 87.7 & $14.7 \%$ & 994.8 & $31.7 \%$ & -907.1 & $35.7 \%$ \\
2005 & 122.1 & $17.3 \%$ & 988.2 & $28.3 \%$ & -866.1 & $31.0 \%$ \\
2006 & 68.2 & $10.0 \%$ & 1210.1 & $35.9 \%$ & -1141.9 & $42.5 \%$ \\
2007 & 82.2 & $10.1 \%$ & 751.5 & $22.7 \%$ & -669.3 & $26.8 \%$ \\
2008 & 35.0 & $3.7 \%$ & 620.8 & $17.8 \%$ & -585.8 & $23.0 \%$ \\
2009 & 35.9 & $3.5 \%$ & 550.8 & $14.5 \%$ & -514.9 & $18.4 \%$ \\
2010 & 18.8 & $1.8 \%$ & 582.2 & $16.4 \%$ & -563.4 & $22.3 \%$ \\
2011 & 97.6 & $7.5 \%$ & 782.1 & $20.4 \%$ & -684.5 & $27.0 \%$ \\
2012 & 74.6 & $5.8 \%$ & 871.7 & $19.9 \%$ & -797.1 & $25.8 \%$ \\
2013 & 97.4 & $7.3 \%$ & 577.3 & $14.2 \%$ & -479.9 & $17.6 \%$ \\
2014 & 87.8 & $6.0 \%$ & 653.8 & $15.5 \%$ & -566.0 & $20.5 \%$ \\
2015 & 57.8 & $3.5 \%$ & 673.4 & $14.0 \%$ & -615.6 & $19.6 \%$ \\
\hline
\end{tabular}

Source: Palestine Central Bureau of Statistics - Ramallah, Palestine.

$* \%$ calculated by researchers

\section{Methodology}

\subsection{Study Problem}

Palestinian exports from Gaza Strip face many difficulties caused by the siege imposed by the Israeli occupation and the closures of all commercial crossings except Kerem Shalom crossing point, which is not equipped with suitable infrastructure required to encourage exports. The current situation leads to higher export costs, particularly transportation costs and thus reduces the competitiveness of agricultural exports from Gaza Strip. This exploratory study aims to answer the following questions:

1. What are the most prominent mechanisms and methods used in the transportation of agricultural exports from the Gaza Strip?

2. What are the transportation costs incurred at each stage?

3. What are the policies and conditions facing agricultural exporters?

4. What are the required export documents and certificates?

5. What are the main difficulties and obstacles facing agricultural exporters?

6. What are the suggestions to overcome these obstacles?

\subsection{Objectives}

The study aims to measure the transport costs incurred by agricultural exports (fresh fruits and vegetables ) from Gaza Strip starting from the production site up to the targeted markets (regional, Gulf and international). In general, the study aims to achieve the following objectives:

1. Shed light on agricultural exports (classifications, size and directions of exports).

2. Determine the mechanisms and transport costs (inland, maritime and air).

3. Clarifications of policies, procedures and conditions imposed by the Palestinian side and the Israeli occupation.

4. Identify the most prominent difficulties and obstacles facing agricultural exports from the Gaza Strip and ways to overcome them.

\subsection{Data Collection}

The present exploratory study focuses on measuring the transportation costs of agricultural exports from Gaza Strip; it's based on descriptive and analytical approach. Secondary data were collected from the Ministry of Agriculture and the Ministry of National Economy, Gaza Chambers of Commerce, Palestinian Central Bureau of Statistics and related international reports and studies.

Data on the costs of inland, maritime and air transport are extremely difficult to obtain from secondary sources. In this study, data will be obtained from interviews held with stakeholders (heads of agricultural associations, unions, government officials from Ministry of Agriculture, Ministry of National Economy). Based on the interviews, we analyzed the cost of export procedure at all sites starting from the production site up to the targeted markets. In addition, the study aims at identifying the most prominent difficulties faced by Palestinian exporters from the Gaza Strip during those stages. 


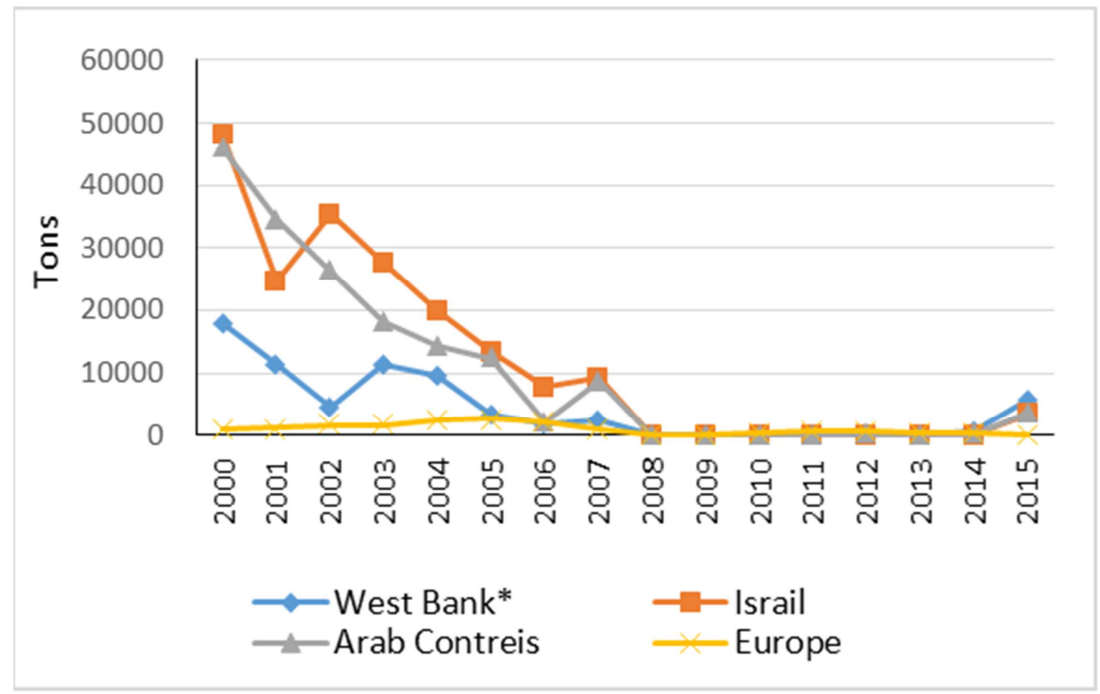

Source: Ministry of Agriculture, Public Management for Marketing and Checking Points, Gaza.

Figure 1. Agriculture Exports from Gaza Strip (Except Flowers).

Table 2. Agriculture Exports from Gaza Strip (2000 - 2015) Quantity in Tones.

\begin{tabular}{lllllll}
\hline Year & West Bank* & Israel & Arab countries & Europe & Total & Rose million \\
\hline 2000 & 17799 & 47969 & 45922 & 979 & 112669 & 62.43 \\
2001 & 11320 & 24722 & 34471 & 1119 & 71632 & 56.41 \\
2002 & 4575 & 35415 & 26230 & 1678 & 67898 & 52.86 \\
2003 & 11492 & 27681 & 18083 & 1688 & 58944 & 49.21 \\
2004 & 9606 & 19957 & 14394 & 2346 & 46303 & 44.22 \\
2005 & 3197 & 13480 & 12344 & 2636 & 31657 & 37.6 \\
2006 & 1788.1 & 7851 & 2179 & 2084 & 13902.1 & 25.5 \\
2007 & 2490.5 & 9137 & 8539 & 1091.6 & 21258.1 & 40.2 \\
2008 & 0 & 0 & 0 & 125 & 125 & 2.1 \\
2009 & 0 & 0 & 0 & 0 & 0 & 1.2 \\
2010 & 0 & 0 & 0 & 227 & 227 & 14.56 \\
2011 & 0 & 0 & 0 & 537.6 & 537.6 & 9.6 \\
2012 & 0 & 0 & 200 & 791 & 991 & 9.7 \\
2013 & 0 & 0 & 16 & 309 & 325 & 1117 \\
2014 & 570 & 0 & 192 & 355 & 104 & 1.84 \\
2015 & 5730 & 3458 & 3695 & 1702.7 & 53032.9 & 0 \\
Average (2000-2007) & 7783.45 & 23276.5 & 20270.25 & 306.075 & 2038.7 & 46.054 \\
Average (2008-2015) & 787.5 & 432.25 & 512.875 & & & 5.425 \\
\hline
\end{tabular}

Source: Ministry of Agriculture, Public Management for Marketing and Checking Points, Gaza.

* Quantitates sold to WB is local trade.

\section{Agriculture Exports from Gaza Strip $\&$ Crossing Movement ${ }^{2}$}

The Gaza Strip exports encounter different restrictions imposed by Israeli occupation particularly since 2007. Palestinian farmers suffered huge losses due to the closure of trade crossing points. In Nov. 2014 Israel allowed some certain agriculture products to be exported through Kerem Shalom which is not suitable for agriculture exports. In 2015

2 The Process of Export and Import to and from Gaza strip was through different commercial Ports (Alawds / Sofa port) close 2008, NahelOwz - Shejaeya closed 2010, Karny Completely close 2011, at the present Kerem Shalom is the only open crossing point, noting that Kerem Shalom is not qualified for commercial operations.
Kerem Shalom worked 243 days and 8 hours instead of 12 hours per day. 1281 trucks were allowed to leave to the West Bank (WB), 1127 trucks comprise agricultural products, at the present time exporting from Gaza Strip is less than 3\% comparing with pre $2007^{3}$.

The process of moving the agricultural products from the exporter's location to the importer's destination involves significant financial costs as well as costs associated with lengthy and uncertain delivery times. The experience of Gaza Strip exporters proves that other procedures imposed by Israeli occupation led to an increase in land transport, freight and logistics cost. Consequently, it has led to great losses to agriculture producers and the other economic sectors.

3 Ministry of Economic, Annual Report 2015, Gaza, Palestine. 
Figure (1) shows the sales of agricultural products to the West Bank and Israel. The average market quantities declined from an average of 53,033 tons per year (2000-2007) to an average 2038.7 tons (2008-2015). Roses export declined from 46.1 million to 5.4 million rose yearly during the compared period, (no roses were exported in 2015).

Table 3. Relative Importance of Agriculture Goods Sold from GS to WB in 2015.

\begin{tabular}{|c|c|c|c|c|c|c|c|c|c|c|c|c|}
\hline Strawberry & Cauliflower & Cheri & Paprika & Cabbage & Dates & Marrow & Pepper & Eggplant & Potato & Tomato & Cucumber & Total \\
\hline 1.3 & 0.2 & 1.7 & 1.9 & 2.8 & 4.7 & 5.9 & 6.5 & 7.9 & 19.3 & 21.3 & 26.5 & 100 \\
\hline
\end{tabular}

Source: Calculated by Researchers Based on Data Published by Ministry of Agriculture, Public Management for Marketing and Checking Points, Gaza.

In 2015, Israel permits the imports of two agricultural items from the Gaza Strip (250 tons tomatoes and 50 tons eggplant per month) and prevented the imports of any other products ${ }^{4}$ Before the 2007 blockade, Israel was the main export destination of agriculture products from Gaza Strip, followed by Arab countries and third by the West Bank. After 2014, the West Bank has become the main market for many types of agricultural products $(44.1 \%$ of agricultural products are sold to West Bank). There is no restriction on marketing agriculture products to the West Bank, except potato, onion and carrot which were banned in 2015. The main product sold to West Bank is cucumber, tomato, sweet potato. Arab countries and Israel are the second and third export destination respectively. The main agricultural products sold to the Arab countries were $57.9 \%$ potato, $41 \%$ tomatoes and $1.1 \%$ pepper in 2015 . The share of Arab countries were about $28.5 \%$, while exports to the European countries contain mainly strawberry, flowers and herbal products in 2015; rose hasn't been exported as shown in table (2) and table (3).

\section{Means of Transportation}

Three means are used to export agriculture goods from the Gaza Strip (inland, maritime, and air transports). Land transport is the most important, followed by air transport. The researcher conducted interviews with the main agriculture exporters and concluded the following facts according to tables (4), (5) and (6) respectively.

\subsection{Land Transport}

Land transport includes road transport, rail and pipelines transport. In the Gaza Strip and the West Bank roads are the only means of transport. After the harvest, the product may be loaded in the farm then directed to Kerem Shalom, such as (hot pepper and flowers) or it may be sent to the packing plant ${ }^{5}$, e.g. Strawberry and potato packed in special packing plant, then directed to the crossing point. The cost for one truck is estimated at $200 \mathrm{New}$ Israeli Sheqalim (NIS). The average exchange rate in 2015 was 1 US $\$=$ NIS 3.85 .

Note truck differences in terms of capacity, weight.... etc.

4 And 5 Interview with Mr. Tahsin Alsaqqa, General Marketing and Ports Manager, Ministry of Agriculture, 17 Feb, 2016, Gaza, Palestine.

5 There are Four Packing plants in the Gaza Strip, three in North Gaza (Agriculture Cooperative - Bit Hanoon, Farmers Union of Strawberry Cooperative - Bit Lahia, Gaza Agriculture Cooperative - Bit Lahia), Agriculture Cooperative for Rose and Vegetables Exports - Khan Younis. as shown in table (4).

Table 4. Truck specifications for agriculture exports ${ }^{6}$.

\begin{tabular}{llll}
\hline Item & $\begin{array}{l}\text { Number of } \\
\text { pallets per truck }\end{array}$ & $\begin{array}{l}\text { Average truck } \\
\text { weight }\end{array}$ & Comments \\
\hline Strawberry & 13 & 2 & $\begin{array}{l}\text { Need refrigeration } \\
\text { trucks }\end{array}$ \\
Herbals & 13 & 2 & \\
Flowers (box) & - & 52 box* & \\
Hot pepper & 13 & 3.25 & \\
Paprika & 13 & 3.25 & \\
Sweet potato & 13 & 3.25 & \\
Tomato & 16 & 10 & \\
Eggplant & 16 & 10 & \\
\hline
\end{tabular}

Exported goods must be ready on pallets according to Israeli conditions, each truck contains between $13-16$ pallets. (Pallet specifications are length 1 meter, width 1.20 m., height $1.60 \mathrm{~m}$.; in the past the height of the pallet was 1.6 $\mathrm{m}$. from the beginning of year 2016).

After being ready, the trucks move to Kerem Shalom (Palestinian side) where the cost of transporting for each nonrefrigerated truck is about NIS400, and about NIS600 for the refrigerated one, while for big truck (non-refrigerated carrying 32 pallet is (NIS) 600.

First, trucks move from the Palestinian side to the Israeli side by loading company ${ }^{7}$ using (Back-to-Back) system which costs NIS 250. Second, from Kerem Shalom Israeli side trucks move to one of three possible destinations, Israel, the West Bank $^{8}$ or Jordan via (King Hussain Bridge); the exporter must pay the transportation cost according to table (5).

Table 5. Truck transport cost from Kerem Shalom to different destinations ${ }^{9}$.

\begin{tabular}{ll}
\hline From Gaza Strip to Final Destination & Transportation cost NIS \\
\hline Kerem Shalom to Israel & $2000^{*}$ \\
Kerem Shalom to West Bank & 2000 to Targomia and 3000 to \\
& Talkarem crossing points \\
West bank crossing points to local cities & 400 \\
Karim Shalom to King Husain Bridge & 4500 for large truck \\
King Husain Bridge to Amman & $2055^{* *}(350-450 \mathrm{JD})$ \\
\hline
\end{tabular}

6 Information was collected by interviews with agriculture Exporters in Gaza Strip.

Abdelraof H. Abu Safar, General Manager Abu Safar Company for Export and Import, Der Elbalah, 12 Feb, 2016.

Ghassan A. Qasem, Member of Management director, Agriculture Cooperative Bit Hanoon, 14 Feb, 2016.

Jamal S. Abu AlNaja, General Manager Agriculture Cooperative for Rose and Vegetables Exports - Khan Younis, 16 Mar, 2016.

7 Shuhaiber is the only transporting Company working in Kerem Shalom.

8 Trucks directed to West Bank are classified as local trade.

9 Based on Information collected from Source No (7). 


\begin{tabular}{ll}
\hline From Gaza Strip to Final Destination & Transportation cost NIS \\
\hline & $9270^{* * *}$ (in normal \\
& conditions the cost range \\
& 8000 to 10000 Saudi Riyal \\
From King Husain Bridge to the main & SR), in other conditions \\
export destination Kingdom of Saudi & (shortage in number of \\
Arabia & trucks), (cost range 10000 to \\
& 14000 SR in April 2015) \\
From King Husain Bridge to Qatar & 12360 (around 12000SR) \\
\hline
\end{tabular}

* NIS 300 added as additional Cost in the case of refrigerated ordinary truck (13 pallets).

** JD 375 is the average cost, and converted to NIS, JD $1=$ NIS 5.48 in to 2015

*** SR 9000 is the average cost, and converted to NIS, SR $1=$ NIS 1.03 in to 2015 .

\subsubsection{The Total Cost of Land Transport}

According to the previous data, we can estimate the cost of land transport by agriculture exporters from Gaza Strip for each ordinary truck (non-refrigerated cargo 13 pallet) as shown in table (6):

Table 6. Truck Transport Cost Matrix from packing Station in Gaza to Final Destination Value NIS.

\begin{tabular}{lll}
\hline & From Gaza Strip \\
\cline { 2 - 3 } From Gaza Strip to Different Destination & $\begin{array}{l}\text { Cost from each } \\
\text { station(NIS) }\end{array}$ & $\begin{array}{l}\text { Total } \\
\text { (NIS) }\end{array}$ \\
\hline Gaza Strip to Kerem Shalom & 400 & 400 \\
Inside Kerem Shalom & 250 & 650 \\
Kerem Shaalom to Israel & 2000 & 2650 \\
Gaza Strip to Targomya crossing point & 2000 & 2650 \\
Targomya crossing point to West bank & 400 & 3050 \\
Gaza Strip to Talkarim & 3000 & 3650 \\
Other cities in the West Bank & 400 & 4050 \\
Karim Shalom to King Husain Bridge & 2250 & 2900 \\
King Husain Bridge to Amman & 1030 & 3930 \\
King Husain Bridge to Saudi Arabia & 4635 & 7535 \\
King Husain Bridge to Qatar & 6180 & 9080 \\
\hline
\end{tabular}

NIS 300 added at every station if exporters use refrigerated trucks.

NIS 200 transport cost (internal transport) must be added from the farm (production point) to the packing station.

\subsubsection{Clearance Charges at the Crossings}

Generally agricultural exports from the Gaza Strip receive government support and encouragement. The exporters pay (NIS 20 per truck) on the Kerem Shalom crossing, no fees paid on trucks heading to the West Bank markets. ${ }^{10}$ Prior to export, according to Israeli conditions, agriculture exporters must send samples of the exported item to be tested in Israel, sample test cost (NIS 400) for each exported item. Agriculture products exported to Israel are subject to free cost, similar test is not required in the case of West Bank. Table (7), illustrates the nature of these duties.

Table 7. Duties paid by Palestinian Exporters at Different Checking points ${ }^{l 1}$.

\begin{tabular}{lll}
\hline Receiver & Duty NIS & Classification \\
\hline Government - Gaza & 20 & Entry fee per truck \\
Israel Occupation - Kerem & 400 & Sample check fee \\
\hline
\end{tabular}

10 Interview with Hatem Ewida, undersecretary Ministry of Economic, 28 Jan, 2016, Gaza.

11 Based on Information collected from Source No (7).

\begin{tabular}{lcl}
\hline Receiver & Duty NIS & Classification \\
\hline $\begin{array}{l}\text { Shalom } \\
\text { Clearance company/king }\end{array}$ & 1500 & Clearance fee per truck* \\
$\begin{array}{l}\text { Husain bridge/ Israel side } \\
\text { Clearance company/king }\end{array}$ & 1010 & \\
Husain bridge/Jordan side & & \\
\hline
\end{tabular}

$200-300$ NIS fee clearance is added for refrigerated trucks.

\subsection{Air Transport}

The importance of air transport for trade has been increasing over time. Air transport is used in the export of some agricultural items, such as (strawberries, roses, hot peppers, herbs), using Israel's "Ben-Gurion" airport. The estimated air transport cost to Europe is about $\$ 1,300$ per ton; additional 22 euros will be paid per pallet from the port of entry to the local cities. Freight plane pallet specifications are 1 meter length, $1.2 \mathrm{~m}$ width, 2.2 meter height, while in the case of passenger plane, pallet should be not more than 1.6 meters high $^{12}$.

\subsection{Sea Transport}

It's possible to export all agricultural products except herbs by maritime, especially to non-Arab countries. The estimated shipping cost is about $\$ 340$ per ton. Shipping takes about six days from Israel, Ashdod sea port to France, Marseille sea port. It is worth mentioning that the shipping is rarely used in the export of agricultural items from the Gaza Strip, where it is primarily relying on road transport, and air transport, especially to Europe. Sea transport represents for many countries the most important mode of transport for trade.

\section{Required Papers \& Documents ${ }^{13}$}

1. Export permission.

2. Shipping invoice and quantity loaded truck.

3. Agricultural test Certificate ${ }^{14}$ - issued by the post-harvest techniques ministry of agriculture.

4. Certificate of origin ${ }^{15}$, there are four forms, namely: certificate of origin especially to Jordan (under the JordanianPalestinian agreement), certificate of origin especially to the Arab countries (under the Agreement on the Facilitation and Development of Trade Exchange between Arab countries), and certificate of origin to the EU countries (EUR1) under the Association Agreement with the European Union (and are currently obtained from Ramallah), and a certificate of origin to export to the rest of the world (Islamic countries, European countries outside the European Union, America and Canada). Other Required Specifications are.

1. High quality certificate.

12 and 14 Interview with Mr. Ghassan A. Qasem, Source No (7)

13 Interview with Mr. Tahsin Alsaqqa, General Marketing and Ports Manager, Ministry of Agriculture, 17 Feb, 2016, Gaza, Palestine

14 Cost Fee NIS 5

15 Cost Fee NIS 50, For Agriculture Export, the Certificate Fee is very low with comparison to the exports of industrial product which is equal to $0.5 \%$ from the total exported value or NIS 150 Minimum, the certificate of origin issued by the chamber of commerce, Gaza Strip. 
2. Clearance of disease and lesions certificate.

3. (GLOBALGAP) GAP is an acronym for Good Agricultural Practices. ${ }^{16}$

\section{Conclusion and Recommendations}

a. The Israeli occupation fully controls all border crossings of the Palestinian Authority and the lack of areal Palestinian role at these crossings. Thus, Israel imposes conditions on the entire export movement.

b. The use of Back-to-Back system in unloading and reloading operations at the crossings points, which takes place twice at the Kerem Shalom crossing, and once again at (Al karama crossing between Jordan and Israel), and three times when exporting through Jordan. Consequently, this system leads to the length of time, high transportation costs, the complexity of clearance procedures and damage to some exporting agricultural items in some cases.

c. A comparative study that was recently conducted by Palestine Trade Center (Pal Trade) highlights the huge differences in export cost for Palestinian and Israeli exporters. The cost for internal transportation (670-835 USD) is 50 percent higher than Israeli companies because Palestinians often have to use two different means of transportation. If Palestinian exporters containerize in the West Bank, containers can be stuffed at 90 percent only to leave space for security checks. On the other hand, if goods are containerized at ports, exporters have to cover the loading cost (Pal Trade 2013). Based on (Pal Trade) findings regarding the West Bank, we are sure that the cost of transportation from the production point in Gaza Strip to Israel's ports will be higher by more than $50 \%$ with comparison to Israeli companies. This is clear evidence of how Palestinian exporters from Gaza Strip and West Bank lose their competitive advantage in the international markets.

d. The closures of all commercial crossings between Gaza Strip and Israel keeping only Kerem Shalom, which is not equipped with the necessary infrastructure for agricultural exports. This is not the only problem, but Israel continues on tightening restrictions against Palestinian exports' movement, where Al Krama "Allenby" becomes the only commercial crossing between Palestine and Jordan and the rest of the Arab world, through which the exports from the Gaza Strip were taken to the rest of the world. Israel closed Prince Mohammad bridge ${ }^{17}$ in 2003 , and thereby exacerbating the crisis facing the Palestinian exports due to the inadequate infrastructure of the King Hussein bridge, high cost, lack of storage capacity, lack of refrigeration

16 (GLOBALGAP) GAP is an acronym for Good Agricultural Practices www.golbalgap.org.

17 Known as Damia Bridge, lies between Jordan and Palestine, used from 1991 to transport goods between West Bank, Israel and Jordan, the bridge was closed during the (Aqsa Intefida) by Israeli Occupation, and trade transactions shifted to King Hussein Bridge. Damia Bridge was declared as a military area in 2014. facilities, and the use of sequencers system, waiting for a long time,,.. etc.

e. Lack of information about export procedures through Israeli ports, and required documents, Israeli ministries... etc., which led to great reliance on Israelis shipping and customs agents. This has led to higher cost of services and time. Further, evidence for highly increased transaction cost was given by a World Bank report "Trading across Borders". Taking into consideration the cost for export documentation and domestic transportation, the report indicates 40 percent higher cost for Palestinians compared to Jordan and 50 percent higher cost than for Israeli exporters

f. Palestine does not have an internationally accredited institution to control the quality of exported products. This institution will help in issuing internationally recognized certificates.

g. Lack of qualified and accredited Palestinians agents, where the full control and export clearance procedures are done through the Israeli private sector.

Based on the foregoing, it is clear that there are many obstacles facing agricultural exports from the Gaza Strip. In general, the following policies and procedures are recommended to reduce the impact of these obstacles and reduce transport costs.

a. The need to put pressure on the Israeli occupation authorities through international official institutions to ensure business continuity in the Kerem Shalom crossing (the only working crossing point currently), and the need to re-open all the commercial crossings that were previously working. Also, this requires increasing the number of daily working hours, the closure of Kerem Shalom crossing and incurred great losses to Palestinian agricultural exporters.

b. The need to work on raising awareness and education of exporters in the Gaza Strip and provide them with knowledge, experience and practical awareness of all the steps that a particular product or shipment traffic pass-through. They lack the execution procedural detail, which significantly affects the cost and time; "Palestine Trade Center" can play an important role.

c. Despite the economic importance of the Palestinian Company "Harvest" for the export of agricultural crops, which provided the opportunity for producers from the Gaza Strip to sell their products in the international markets, especially to Europe such as, strawberries and sweet peppers, which are exported in cardboard boxes labeled with the product name and its origin in Gaza Strip. In the previous years, it was exported in cardboard boxes printed in Hebrew without mentioning that it was a product of Palestine. The Palestinian Company "Harvest" remains unable to provide all the necessary services for the Palestinian exporters, as well as it deals with Israeli marketing companies (subcontracting) as mentioned by some exporters and agricultural cooperatives in Gaza Strip. Therefore, it's necessary to establish other marketing companies for 
Palestinian exports that might receive international support, which contributes to the promotion of agricultural exports, and raise their competitiveness in foreign markets, and reduces costs.

d. The need to establish agricultural export fund to support exporters against losses caused by bad weather and crop failures, or other

e. Measures related to the closure, high transport and customs costs at the crossing points, in order to ensure the continuation of the production process and supporting the exporter's capabilities. The agricultural export fund could be financed by donor countries or some regional and international institutions.

f. Transparency system is required to determine the tasks, objectives, and mechanisms of the fund to ensure success.

\section{References}

[1] Behar Alberto and Venables Anthony J (2010), Transport Costs and International Trade, Paper written for Handbook of Transport Economics, eds André de Palma, Robin Lindsey, Emile Quinet\& Roger Vickerman.

[2] Ben Shepherd (2013). Aid for Trade and Value Chains in Transport and Logistics@ OECD/WTO.

[3] Christ, Nannette, Ferrantino, Michael J (2009), Land Transport for Exports: The Effects of Cost, Time, and Uncertainty in Sub-Saharan Africa, U.S. International Trade Commission" Washington, DC 20436 USA.

[4] Coşar A. Kerem, Demir Banu (2015) Domestic Road Infrastructure and International Trade: Evidence from Turkey, Journal of Development Economics 118 (2016) 232-244.

[5] Inmaculada Martínez-Zarzoso, Eva Maía Pérez García and Celestino Suárez-Burguet (2008), do Transport Costs have a
Differential Effect on Trade at the Sectoral level? Applied Economics, Taylor \& Francis (Routledge), 2008, 40 (24), pp.3145-3157.

[6] Jean-François Arvis, Yann Duval, Ben Shepherd, and Chorthip Utoktham (2013), Trade Costs in the Developing World: 1995-2010, Policy Research Working Paper 6309, World Bank.

[7] Kleinert, Jörn; Spies, Julia (2011), Endogenous Transport Costs in International Trade, IAW-Diskussionspapiere, No. 74.

[8] Korinek, J. and P. Sourdin (2011), "To What Extent Are HighQuality Logistics Services Trade Facilitating?” OECD Trade Policy Papers, No. 108, OECD Publishing. http://dx.doi.org/10.1787/5kggdthrj1 zn-en

[9] Palestine Trade Center (2013), Reaching the Untapped Potential, Enhancement of Trade between the European Union and the State of Palestine.

[10] Stone, S., and A. Strutt (2009), Transport Infrastructure and Trade Facilitation in the Greater Mekong Subregion. ADBI Working Paper 130. Tokyo: Asian Development Bank Institute. Available: http://www.adbi.org/workingpaper/ 2009/01/20/2809.transport.infrastructure.trade.facilitation.mek ong/

[11] UNCTAD Secretariat (2013), Recent developments and trends in international maritime transport affecting trade of developing countries. Trade \& Development Board, Trade and Development Commission, Fifth session, Geneva, 17-21 June 2013, Item 5 of the provisional agenda.

[12] World Bank: Trading Across Borders. URL: http://www.doingbusiness.org/data/exploretopics/tradingacross-borders (a dataset that provides estimates of bilateral trade costs in agriculture and manufactured goods for the 1995-2010 period).

[13] World Trade Report (2004), Infrastructure in Trade and Economy, Development II COHERENCE. 